\title{
Copper(II)-catalyzed Formation of 1,3-Dioxolanes from Oxiranes
}

\author{
Seung-Han Lee, Jae-Chul Lee, Ming-Xing Li, and Nam-Sun Kim \\ Department of Chemistry, Kyunghee University, Yongin 449-701, Korea. ${ }^{*}$ E-mail: shlee@khu.ac.kr \\ Received November 20, 2004
}

Key Words : 1,3-Dioxolane, Oxirane, Copper catalyst, Rearrangement

1,3-Dioxolanes are widely used as protecting groups for the carbonyls and 1,2-diols in the synthetic chemistry of carbohydrates and steroids. ${ }^{1}$ They are often prepared from oxiranes with carbonyl compounds in the presence of Brønsted ${ }^{2}$ or Lewis acids including $\mathrm{BF}_{3},{ }^{3} \mathrm{CuSO}_{4},{ }^{4} \mathrm{Bi}(\mathrm{III}),{ }^{5}$ $\mathrm{Sn}(\mathrm{IV}),{ }^{3 \mathrm{~d}, 6} \mathrm{Ti}(\mathrm{IV}),{ }^{7} \mathrm{Ir},{ }^{8} \mathrm{Ru}(\mathrm{III}){ }^{9}$ and Re catalysts. ${ }^{10}$ However, these methodologies limit the general synthesis of various dioxolanes due to the low yields, relatively long reaction times, the use of large amounts of catalyst, and the lack of reactivity depending on the types of oxiranes. In the course of our mechanistic studies on catalytic reactions of $\mathrm{Cu}$ (II), imines, and ethyl diazoacetate (EDA) in acetone, ${ }^{11}$ we observed $\mathrm{Cu}(\mathrm{II})$ catalyzed the reaction of carbonyl compounds with EDA to give the corresponding 1,3-dioxolanes (Scheme 1). The copper catalyst might act as Lewis acid to form the 1,3-dipolar intermediates or oxiranes which further react with carbonyl compounds to give the 1,3-dioxolanes. ${ }^{12}$

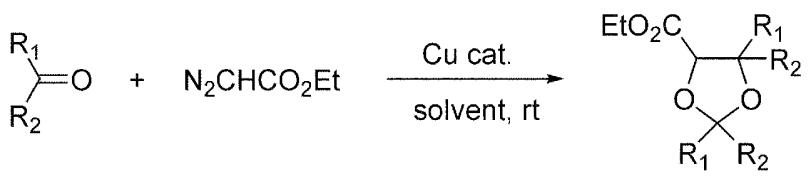

Scheme 1

Thus, the preparation of 1,3-dioxolanes from epoxides has been investigated using copper catalyst in acetone solvent (Scheme 2). Both aryloxiranes and alkyloxiranes gave the corresponding1,3-dioxolanes in moderate to high yields in the presence of copper(II) triflate in acetone at room temperature (Table 1). ${ }^{13}$ The two diastereomers were separated by chromatography and their structures were determined by ${ }^{1} \mathrm{H}$ NMR. ${ }^{4}$

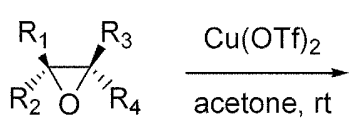

1

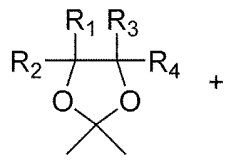

2

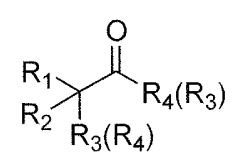

3
Scheme 2

The rate of dioxolane forming reaction is dependent on the nature of the substituents on the oxirane ring. In case of aryloxiranes, the rate of product formation was fast in the presence of $2 \mathrm{~mol} \%$ of catalyst and the reaction was completed within $4 \mathrm{~h}$ at room temperature (Table 1, entries
Table 1. 1,3-Dioxolane Formation from Oxiranes Using $\mathrm{Cu}(\mathrm{II})$ Catalyst in Acetone

\begin{tabular}{cccccccc}
\hline Entry Epoxide & $\mathrm{R}_{1}$ & $\mathrm{R}_{2}$ & $\mathrm{R}_{3}$ & $\mathrm{R}_{4}$ & $\begin{array}{c}\mathbf{2}(\%)^{a} \\
{\text { trans } / \text { cis })^{b}}^{b}\end{array}$ & $\begin{array}{c}\mathbf{3} \\
(\%)\end{array}$ \\
\hline 1 & $\mathbf{1 a}$ & $\mathrm{Ph}$ & $\mathrm{H}$ & $\mathrm{H}$ & $\mathrm{H}$ & 87 & 12 \\
2 & $\mathbf{1 b}$ & $\mathrm{Ph}$ & $\mathrm{H}$ & $\mathrm{H}$ & $\mathrm{Me}$ & $87(1.0)$ & 12 \\
3 & $\mathbf{1 c}$ & $\mathrm{Ph}$ & $\mathrm{H}$ & $\mathrm{Me}$ & $\mathrm{H}$ & $82(2.3)$ & 17 \\
4 & $\mathbf{1 d}$ & $\mathrm{Ph}$ & $\mathrm{H}$ & $\mathrm{H}$ & $\mathrm{CO}_{2} \mathrm{Me}$ & $82(1.7)$ & 8 \\
5 & $\mathbf{1 e}$ & $\mathrm{Ph}$ & $\mathrm{H}$ & $\mathrm{H}$ & $\mathrm{Ph}$ & $72(1.7)$ & 25 \\
6 & $\mathbf{1 f}$ & $\mathrm{Ph}$ & $\mathrm{H}$ & $\mathrm{Ph}$ & $\mathrm{H}$ & $72(4.0)$ & 21 \\
7 & $\mathbf{1 g}$ & $\mathrm{Ph}$ & $\mathrm{Me}$ & $\mathrm{H}$ & $\mathrm{Ph}$ & $85(16)$ & 13 \\
8 & $\mathbf{1 h}$ & $\mathrm{PhCH}_{2}$ & $\mathrm{H}$ & $\mathrm{H}$ & $\mathrm{H}$ & 72 & - \\
9 & $\mathbf{1 i}$ & $\left(\mathrm{CH}_{2}\right)_{2}$ & $\mathrm{H}$ & $\left(\mathrm{CH}_{2}\right)_{2}$ & $\mathrm{H}$ & 87 (trans only) & - \\
10 & $\mathbf{1 j}$ & $n-\mathrm{C}_{4} \mathrm{H}_{9}$ & $\mathrm{H}$ & $n-\mathrm{C}_{4} \mathrm{H}_{9}$ & $\mathrm{H}$ & 62 (trans only) & 34 \\
\hline
\end{tabular}

${ }^{a}$ Isolated yields. ${ }^{b}$ Ratios were determined by ${ }^{1} \mathrm{H}$ NMR analysis. ${ }^{c}$ Reaction time is 2 days.

1-7). With alkyloxiranes the rate of product formation was slow under same reaction conditions and the reaction was performed using $5 \mathrm{~mol} \%$ of copper triflate for longer reaction times $(7 \mathrm{~h})$ (Table 1, entries 9-10). Especially the rate of monoalkyl-substituted oxirane was very slow at room temperature (entry 8). The Lewis acid-catalyzed reaction of an oxirane with a carbonyl compound proceeds via complexation of the acid with the oxygen atom of oxirane, followed by nucleophilic attack on the oxirane by the carbonyl oxygen to form the dioxolane ring formation. Therefore, inversions of configuration have been found to occur for Lewis acid catalyzed additions of oxiranes to carbonyls. However, the reaction of aryloxiranes under present reaction conditions was found to be less stereoselective and both cis- and trans-phenyloxiranes gave transdioxolanes as major products (Table 1, entries 3-6). On the other hand, trans- $\alpha$-methylstilbene oxide $1 \mathrm{~g}$ showed the higher stereoselectivity (entry 7). In contrast to aryloxiranes, the reaction of alkyloxiranes was completely stereospecific, cis-alkyloxiranes giving only trans-dioxolanes (entries 910).

The dioxolane formation reactions also gave the rearranged aldehydes or ketones as side products. Lewis acid catalyzed rearrangement of oxiranes to carbonyl compounds is well-known reaction. This reaction proceeds by coordination of a Lewis acid on the oxygen atom, cleavage of a C-O bond to form an electron-deficient carbon center at the more substituted carbon atom, and migration of a substituent to 
the adjacent carbon center with simultaneous formation of a carbonyl compound. Although $\mathrm{BF}_{3} \cdot \mathrm{Et}_{2} \mathrm{O},{ }^{14} \mathrm{Pd}(\mathrm{OAc})_{2}{ }^{15}$ $\mathrm{InCl}_{3},{ }^{16} \mathrm{Bi}(\mathrm{III}),{ }^{17} \mathrm{Fe}(\mathrm{III}),{ }^{18}$ and $\mathrm{VO}(\mathrm{OEt}) \mathrm{Cl}_{2}{ }^{19}$ were reported for this purpose, a few are both regioselective and catalytic. 1-Aryloxiranes (entries 1-4) underwent rearrangement by hydride shift to give the corresponding aryl-substituted carbonyls as the only isolable compounds. On the other hand, stilbene oxides underwent phenyl migration instead of hydrogen to afford the corresponding diphenylacetaldehydes (entries 5-7). The rearranged carbonyl compounds of alkyloxiranes were not observed except for cis-decene oxide 1j (entries 8-10). Presumably, the carbocation formed by the initial cleavage of oxirane is much less stabilized in alkylsubstituted oxirane compared to that in aryl-substituted one.<smiles></smiles>

$$
\frac{\mathrm{Cu}(\mathrm{OTf})_{2}}{\mathrm{CH}_{2} \mathrm{Cl}_{2}, 40 \mathrm{~min}, \mathrm{rt}}
$$

$1 \mathrm{e}$<smiles>O=CC(c1ccccc1)c1ccccc1</smiles>

$3 e$

\section{Scheme 3}

The rearrangement reaction was performed in dichloromethane in the presence of $2 \mathrm{~mol} \% \mathrm{Cu}(\mathrm{OTf})_{2}$ at room temperature and trans-stilbene oxide 1e underwent rapid rearrangement to afford 2,2-diphenylethanal $3 \mathbf{e}$ in $98 \%$ yield (Scheme 3).

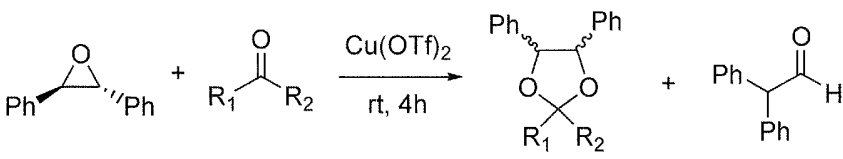

$$
\begin{aligned}
& \mathrm{R}_{1}=\mathrm{R}_{2}=\mathrm{Et} ; \quad 31 \% \text { (trans } / \text { cis }=2.8 \text { ) } \quad 64 \%
\end{aligned}
$$

Scheme 4

1,3-Dioxolane formation reactions were performed from trans-stilbene oxide in 3-pentanone and cyclopentanone instead of acetone solvent (Scheme 4). Higher yield was obtained with cyclopentanone in comparison with 3-pentanone which is sterically encumbered compound. ${ }^{3 a, 10}$

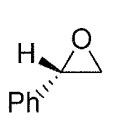

(S)-Styrene oxide

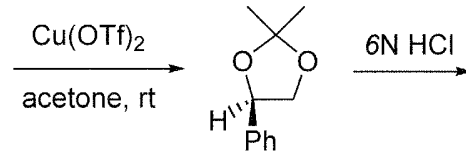

(R)-Dioxolane

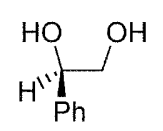

(R)-Diol
Scheme 5

Also, chiral $(S)$-styrene oxide was converted into the corresponding optically active $(R)$-2,2-dimethyl-4-phenyl1,3 -dioxolane in $87 \%$ yield and $43 \%$ ee. Optical purity was determined by GC analysis (Supelco Chiral cyclo $\beta$-DEX 325 ) for 1,2-diol which was obtained from the hydrolysis of 1,3-dioxolane (Scheme 5).

In summary, we prepared 1,3-dioxolanes in high yields from oxiranes using copper triflate as Lewis acid catalyst in acetone solvent. Also, trans-stilbene in dichloromethane afforded the rearranged carbonyl compound in high yield. Investigations concerning the copper-catalyzed regioselective rearrangement of oxiranes to aldehydes or ketones are underway.

Acknowledgment. This work was supported by the Brain Korea 21 Project.

\section{References}

1. Greene, T. W.; Wuts, P. G. M. Protective Groups in Organic Synthesis, 3rd Ed.; John Wiley \& Sons: New York, 1999; pp 323329.

2. Bucsi, I.; Meleg, A.; Molnár, Á.; Bartók, M. J. Mol. Catal. A: Chem. 2001, 168, 47-52.

3. (a) Torok, D. S.; Figueroa, J. J.; Scott, W. J. J. Org. Chem. 1993, 58, 7274-7276. (b) Colvin, E. W.; Robertson, A. D.; Wakharkar, S. J. Chem. Soc., Chem. Commun. 1983, 312-314. (c) Blackett, B. N.; Coxon, J. M.; Hartshorn, M. P.; Lewis, A. J.; Little, G. R.; Wright, G. J. Tetrahedron 1970, 26, 1311-1313. (d) Dryuk, V. C.; Avramenko, V. I.; Yandovskii, V. N. J. Chem. Soc., Perkin Trans. 2 1977, 1526-1529.

4. Hanzlik, R. P.; Leinwetter, M. J. Org. Chem. 1978, 43, 438-440.

5. Mohammadpoor-Baltork, I.; Khosropour, A. R.; Aliyan, H. Synth. Commun. 2001, 31, 3411-3416.

6. Tangestaninejad, S.; Habibi, M. H.; Mirkhani, V.; Moghadam, M. J. Chem. Res. (S) 2001, 365-367.

7. (a) Iranpoor, N.; Zeynizadeh, B. J. Chem. Res. (S) 1998, 466-467. (b) Nagata, T.; Takai, T.; Yamada, T.; Imagawa, K.; Mukaiyama, T. Bull. Chem. Soc. Jpn. 1994, 67, 2614-2616.

8. Adams, R. D.; Barnard, T. S.; Brosius, K. J. Organomet. Chem. 1999, 582, 358-361.

9. Iranpoor, N.; Kazemi, F. Synth. Commun. 1998, 28, 3189-3193.

10. Zhu, Z.; Espenson, J. H. Organometallics 1997, 16, 3658-3663.

11. Lee, S.-H.; Yang, J.; Han, T.-D. Tetrahedron Lett. 2001, 42, 34873490.

12. Doyle, M. P.; Forbes, D. C.; Protopopova, M. N.; Stanley, S. A.; Vasbinder, M. M.; Xavier, K. R. J. Org. Chem. 1997, 62, 72107215.

13. Under nitrogen atmosphere, to a stirred solution of $\mathrm{Cu}(\mathrm{OTf})_{2}$ $(0.02 \mathrm{mmol}, 0.02$ equiv) in acetone $(3 \mathrm{~mL})$ was added oxirane (1.0 mmol, 1.0 equiv) at room temperature. After stirring for $4 \mathrm{~h}$, the reaction mixture was concentrated, dissolved in ether, and filtered through silica gel. The ethereal solution was concentrated in vacuo and chromatographed on silica gel $($ EA $:$ hexane $=1: 5)$.

trans-2,2,4-Trimethyl-5-phenyl-1,3-dioxolane (trans-2b): ${ }^{1} \mathrm{H}$ NMR $\left(400 \mathrm{MHz}, \mathrm{CDCl}_{3}\right) \delta 7.39-7.27(\mathrm{~m}, 5 \mathrm{H}), 4.47(\mathrm{~d}, J=8.5 \mathrm{~Hz}$, $1 \mathrm{H}), 3.88-3.84(\mathrm{~m}, 1 \mathrm{H}), 1.56(\mathrm{~s}, 3 \mathrm{H}), 1.52(\mathrm{~s}, 3 \mathrm{H}), 1.29(\mathrm{~d}, J=6.0$ $\mathrm{Hz}, 3 \mathrm{H}) ;{ }^{13} \mathrm{C}$ NMR $\left(100 \mathrm{MHz}, \mathrm{CDCl}_{3}\right) \delta 137.50,128.41,128.10$, 126.39, 108.37, 84.80, 79.22, 27.50, 27.01, 16.25; IR (KBr) 2984, 2932, 2875, 1494, 1378, 1239, 1174, 1095, $752 \mathrm{~cm}^{-1}$.

14. Hara, N.; Mochizuki, A.; Tatara, A.; Fujimoto, Y. Tetrahedron: Asymmetry 2000, 11, 1859-1868.

15. Kulasegaram, S.; Kulawiec, R. J. J. Org. Chem. 1997, 62, 65476561.

16. Ranu, B. C.; Jana, U. J. Org. Chem. 1998, 63, 8212-8216.

17. (a) Anderson, A. M.; Blazek, J. M.; Garg, P.; Payne, B. J.; Mohan, R. S. Tetrahedron Lett. 2000, 41, 1527-1530. (b) Bhatia, K. A.; Eash, K. J.; Leonard, N. M.; Oswald, M. C.; Mohan, R. S. Tetrahedron Lett. 2001, 42, 8129-8132.

18. Suda, K.; Baba, K.; Nakajima, S.; Takanami, T. Tetrahedron Lett. 1999, 40, 7243-7246.

19. Martinez, F.; Campo, C.; Llama, E. F. J. Chem. Soc., Perkin Trans. 1 2000, 1749-1751. 